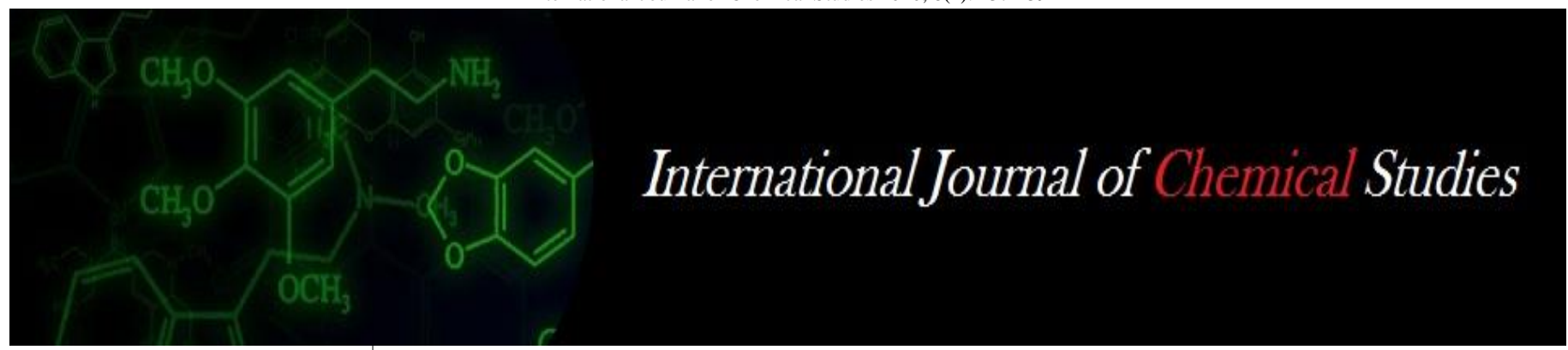

P-ISSN: 2349-8528

E-ISSN: 2321-4902

www.chemijournal.com

IJCS 2020; 8(2): 237-239

(C) 2020 IJCS

Received: 10-01-2020

Accepted: 12-02-2020

Divya Rai

Department of Plant Pathology,

B.M. College of Agriculture

Khandwa, Rajmata Vijaya Raje

Scindia Krishi Vishwa Vidyalaya,

Gwalior, Madhya Pradesh, India

Pramod Kumar Fatehpuria

Department of Plant Pathology,

B.M. College of Agriculture

Khandwa, Rajmata Vijaya Raje

Scindia Krishi Vishwa Vidyalaya,

Gwalior, Madhya Pradesh, India

Ajay Singh Kaurav

Department of Plant Pathology,

B.M. College of Agriculture

Khandwa, Rajmata Vijaya Raje

Scindia Krishi Vishwa Vidyalaya,

Gwalior, Madhya Pradesh, India

Rajni Singh Sasode

Department of Plant Pathology,

B.M. College of Agriculture

Khandwa, Rajmata Vijaya Raje

Scindia Krishi Vishwa Vidyalaya,

Gwalior, Madhya Pradesh, India

Hemant Trivedi

Department of Plant Pathology, B.M. College of Agriculture

Khandwa, Rajmata Vijaya Raje

Scindia Krishi Vishwa Vidyalaya,

Gwalior, Madhya Pradesh, India

PP Sastry

Department of Plant Pathology,

B.M. College of Agriculture

Khandwa, Rajmata Vijaya Raje

Scindia Krishi Vishwa Vidyalaya,

Gwalior, Madhya Pradesh, India

Corresponding Author:

Pramod Kumar Fatehpuria

Department of Plant Pathology,

B.M. College of Agriculture

Khandwa, Rajmata Vijaya Raje

Scindia Krishi Vishwa Vidyalaya,

Gwalior, Madhya Pradesh, India

\section{Survey of anthracnose disease of chilli, Eastern Nimar region of Madhya Pradesh}

\author{
Divya Rai, Pramod Kumar Fatehpuria, Ajay Singh Kaurav, Rajni Singh \\ Sasode, Hemant Trivedi and PP Sastry
}

DOI: https://doi.org/10.22271/chemi.2020.v8.i2d.8775

\section{Abstract}

Chilli (Capsicum annuum) is an important spice as well as vegetable worldwide cultivated crop. It is used in many cuisines but also found to have many medicinal properties. Chilli (Capsicum annum L.) is an important cash crop of East Nimar region of M.P. In Khandwa chilli is grown in 4,298 ha area with 22, 349-ton annual production (Anonymous 2015). The percent disease incidence in Khandwa district is $29.56 \%$ and it varies from $35.90 \%$ to $21.90 \%$. The maximum incidence was recorded in Jaswadi (35.90\%) followed by Titiysa (32.70\%), Rustampur (29.80\%), Singot $(27.50 \%)$. and Chegav makhan $(21.90 \%)$.

Keywords: Capsicum annuum, survey, anthracnose disease

\section{Introduction}

Chilli (Capsicum annuum) is an important spice as well as vegetable worldwide cultivated crop. It is used in many cuisines but also found to have many medicinal properties. It belongs to the family Solanaceae. Green chillies are rich source of vitamins especially vitamin A, C, B1 and B2 (Saimbhi et al., 1977; Sayed and Bhagvandas, 1980) ${ }^{[11]}$ and is also rich in vitamin $\mathrm{P}$ (rutin), which is of immense pharmaceutical importance. Pungency in chilli, is due to the presence of Capsaicin, a digestive stimulant and a cure for rheumatic troubles. The fruit of Capsicum has a variety of names, such as 'chilli', 'chilli pepper' or 'pepper' depending on place (i.e., differences between the English-speaking countries) and type of fruits. India is largest producer with $36 \%$ share in global production (Sahitya et. al, 2014). Indian chilli is considered to be world famous for two important commercial qualities like colour and pungency levels. Some varieties are famous for the red colour because of the pigment "Capsanthin" and others are known for biting pungency attributed to Capsaicin green. China, India, Mexico, Morocco, Pakistan, Thailand and Turkey are the most important exporters of chilli. However, the average productivity of dry chilli is low (1 ton/ha) in India as compared to China, Taiwan, and Mexico where it yields 3 tons per ha. (Peter, 1998) ${ }^{[9]}$. The main reason for the low productivity in India is the cultivation of open pollinated varieties which do not have the genetic capacity to break the yield barriers, (Kaur et al, 2011) ${ }^{[7]}$. Chili is mainly cultivated in tropical and sub - tropical countries of the world and India is the largest producer of chili in the world accounting for over $45 \%$ of the total area under cultivation. Andhra Pradesh, Maharashtra, Karnataka, Orissa and Tamil Nadu account for about $75 \%$ of the total area as well as production of India. In Madhya Pradesh chilli is grown in about $0.54 \mathrm{mh}$ area with 0.93 $\mathrm{mt}$ annual production (Anonymous 2015) ${ }^{[1]}$. Chilli (Capsicum annum L.) is an important cash crop of East Nimar region of M.P. In Khandwa chilli is grown in 4,298 ha area with 22, 349ton annual production (Anonymous 2015) ${ }^{[1]}$. The occurrence of diseases caused by fungi, bacteria and viruses greatly hampers the production of chilli. This crop suffers from about more than 40 fungal diseases (Rangaswami, 1979) ${ }^{[10]}$. Out of which Anthracnose of chilli is one of the major and devastating diseases of chilli causes severe losses (10-60\%) both in yield and quality of the chilli depending upon the varieties (Bansal and Grover, 1969) ${ }^{\text {[3]. }}$ Colletotrichum capsici is the most important plant pathogen worldwide, causing economically important disease anthracnose. The pathogen is seed, soil, and air borne. The disease is prevalent in almost all major chilli growing areas and it is reported to cause $25-48 \%$ loss in different parts of India (Datar, 1995; Fugro, 2000, Ekbote, 2001 and Rathore, 2006) ${ }^{[5,6]}$. 
Survey was carried out for recording the incidence of anthracnose of chilli grown in some farmer's field in Khandwa districts at different stages of plant growth. In each village five survey plots were selected randomly from field where the chilli crop was grown. Different locations were surveyed during Kharif season 2017-18 for assessing the intensity of the disease. Some plants from each cultivar or crop were taken randomly every time from each locality, symptoms and prevalence of Colletotricum sp. on chilli under in Khandwa conditions. The percent disease intensity (PDI) calculated as follows: For such survey five villages of Khandwa district in three chilli growing blocks were randomly selected and from each village five fields were randomly selected. In each field the incidence of anthracnose of chilli was recorded on five $1 \mathrm{~m}^{2}$ patches by counting the infected plant and total number of plants. The data is summarized indicates (table-1) that the disease incidence in Khandwa district was $29.56 \%$ and it varies from $35.90 \%$ to $21.90 \%$ from block to block while the maximum incidence was recorded in Jaswadi $(35.90 \%)$ followed by Titiya (32.70\%), Rustampur (29.80\%), Singot $(27.50 \%)$. and Chegav Makhan $(21.90 \%)$. The variations may principally be due to three reasons choice of hybrid, cropping pattern (monocropping of chilli) where buildup of inoculum takes place and crop nutrition (heavy dose of nitrogenous fertilizers). Such variations in anthracnose severity and wide spread nature have been reported by earlier workers. Anamika et al. (2012) ${ }^{[2]}$ conducted a survey to assess the incidence of anthracnose of chilli in five locations in Rewa Province. The percentage incidence of anthracnose was observed to be in the range of 55.53 and $71.10 \%$. It was revealed that predominant presence of the anthracnose disease is varied by environmental factors and inoculum presence in particular place. The present findings are in agreement with the earlier reports of Ekbote (2002) [7] who conducted a survey of the prevalent diseases of chilli (Capsicum annuum) in 6 taluks in the Haveri district of Karnataka. Fruit rot caused by Colletotrichum capsici was found to varies around $42.00 \%$ and similar results were reported by Chigoziri et al. (2013) ${ }^{[4]}$ from Gboko and Ohimini, South Nigeria. It is thus clear that Anthracnose of chillies is widespread and a major constraint. Anthracnose is also predominant in chilli growing pockets of the Nimar Valley in Madhya Pradesh

Table 1: Survey of Anthracnose of Chilli in Khandwa district of Madhya Pradesh.

\begin{tabular}{|c|c|c|}
\hline District & Village & Percent disease incidence \\
\hline \multirow{4}{*}{ Khandwa } & Jaswadi & 35.90 \\
\cline { 2 - 3 } & Titiya & 32.70 \\
\cline { 2 - 3 } & Rustampur & 29.80 \\
\cline { 2 - 3 } & Singot & 27.50 \\
\cline { 2 - 3 } & Chegav Makhan & 21.90 \\
\hline & Mean & 29.56 \\
\hline
\end{tabular}

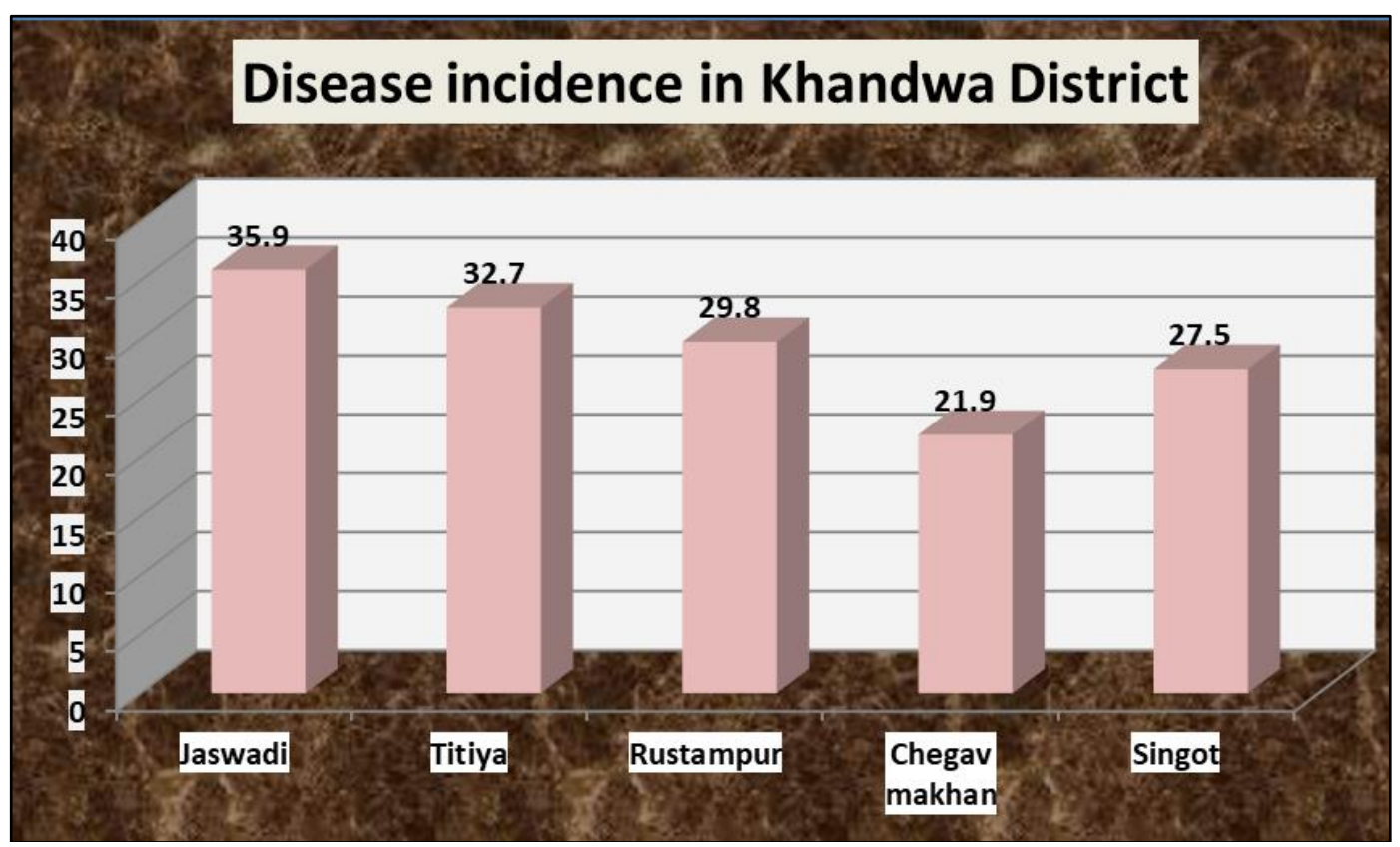

Fig 1: Survey of anthracnose of chilli in Khandwa district of Madhya Pradesh.

\section{References}

1. Anon. Horticultural Statistics at a Glance published by Horticulture Statistics Division New Delhi, 2015, 463.

2. Anamika Rhoda S, Nath P. Survey of anthracnose disease in chilli crop in Rewa region. Inter. J Sci. Res. 2012; 3(8):1851-1854.

3. Bansal RD, Grover RK. Reaction of chilli (Capsicum frutescens) against Colletotrichum capsici. Inter. J Agric. Crop Sci. 1969; 5(7):723-730.

4. Chigoziri E, Ekefan EJ. Seed borne fungi of Chilli Pepper (Capsicum frutescens) from pepper producing areas of Benue State, Nigeria. Agric. Bio. J North America. 2013; 4(4)370-374
5. Datar VV. Pathogenicity and effect of temperature on six fungi causing fruit rot chilli. J Mycol. Pl. Pathol. 1995; 25:312-313.

6. Ekbote SD. Survey for chilli disease in Haveri district of Karnataka. J Agric. Sci. 2001; 15:726-728.

7. Ekbote SD, Padaganur GM, Patil MS, Chattanwar, SN. Studies on the cultural and nutritional aspects of Colletotrichum gloeosporioides, the causal organism of mango anthracnose. J Mycol Pl Path. 1997; 27(2):229230.

8. Kaur N, Dhiman JS, Khurana DS. Physiological and biochemical traits analysis of Capsicum annum L.germplasm for resistance to Colletotrichum capsici. Cell Pl Sci. 2011; 2(3):12-21. 
9. Peter KV. Recent advances in chilli breeding. Indian Species. 1998; 35:3-5.

10. Rangaswami G. Disease of crop plants in India, PrinticeHall of India Private Ltd. New Delhi, India, 1979, 570.

11. Saimbhi MS, Kan G, Nandpuri KS. Chillies are rich in vitamins especially vitamin C. Qualita Plantarum. 1977; 27:171-175. 